\title{
Pemodelan Persamaan Navier-Stokes untuk Aliran Fluida Tidak Termampatkan
}

\author{
(Modeling of the Navier-Stokes Equation for the Flow of Incompressible Fluid)
}

\author{
Joko Eliyanto ${ }^{1 *}$, Julan Hernadi ${ }^{2}$ \\ Matematika, Universitas Ahmad Dahlan, Jalan Ring Road Selatan, Tamanan, Bantul, Daerah Istimewa \\ Yogyakarta, 55191 \\ E-mail: joko1400015006@webmail.uad.ac.id \\ * Corresponding Author
}

\begin{tabular}{ll}
\hline ARTICLE INFO & ABSTRACT \\
\hline Kata Kunci & Kajian ini membahas pemodelan persamaan Navier-Stokes pada aliran fluida \\
Persamaan Naiver-Stokes & yang tidak termampatkan. Fluida diasumsikan tidak mengalami perubahan \\
Persamaan Kontinuitas & massa jenis(densitas) akibat aliran. Pemodelan persamaan ini didasarkan pada \\
Persamaan Momentum & hukum-hukum dasar fisika yaitu hukum kekekalan massa dan hukum Newton \\
dua. Tujuan skripsi ini adalah memodelkan aliran fluida ke dalam bentuk & persamaan diferensial yang kemudian dapat dicari aproksimasi solusinya dan \\
Keywords & dapat disimulasikan secara numerik menggunakan metode beda hingga. \\
Naiver-Stokes Equation & Metode yang digunakan pada skripsi ini berupa studi pustaka dengan mengkaji \\
Continuity Equation & dan mengembangkan literatur yang berhubungan dengan persamaan Navier- \\
Momentum Equation & Stokes untuk aliran fluida yang tidak termampatkan dan ilmu mekanika fluida. \\
& Berdasarkan hukum kekekalan massa diperoleh persamaan kontinuitas \\
kemudian berdasarkan hukum Newton ke-dua diperoleh persamaan \\
momentum, kedua persamaan ini digabungkan menjadi suatu sistem persamaan \\
diferensial parsiel nonlinear orde dua yang dikenal sebagai persamaan Navier- \\
Stokes. Aliran dalam rongga disimulasikan secara grafis menggunakan \\
persamaan yang telah diperoleh dan menghasilkan simulasi yang \\
merepresentasikan aliran fluida sesungguhnya pada aliran dalam rongga.
\end{tabular}

This research explains about modelling of Navier-Stokes in unclogged fluid flow. Fluid is assumed as not having a density change because of the flow. This equation modelling is based on physic's basic laws, such as Law of Conservation of Energy and Newton's Second Law of Motion. The goal of this study is to model the fluid flow to a differential equation which then could be used to find its approximation solution and simulated numerically using finite difference method. The method used in this study is a literature review while also developing any literature that is related to Navier-Stokes Equation for unclogged fluid flow and knowledge about mechanical fluid. Law of Conservation of Energy then resulted on continuity equation while Newton's Second Law of Motion resulted on momentum equation. These 2 equations are combined resulting on an second orde of nonlinear partial differential equation which also known as Navier-Stokes equation. The flow in the cavity is simulated graphically using the obtained equation and resulting on simulation that represents the real fluid flow in cavity flow.

This is an open access article under the CC-BY-SA license.

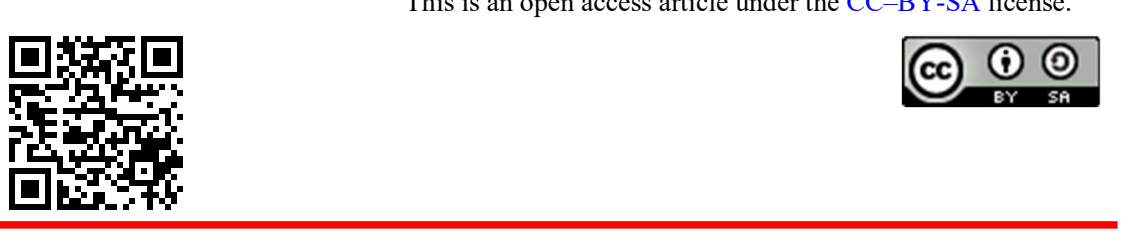




\section{PENDAHULUAN}

Pemodelan matematika merupakan suatu proses di mana permasalahan pada dunia nyata disajikan dalam bentuk permasalahan matematika, seperti sistem persamaan linear, persamaan tak linear, persamaan diferensial yang memuat masalah nilai awal dan syarat batas, persamaan integral, masalah optimasi dan kontrol, dan lain sebagainya [1][2][3]. Pada kajian ini, akan dibahas tentang pemodelan aliran fluida. Aliran fluida merupakan suatu fenomena alam yang kita temui setiap hari. Dampak dari aliran fluida sangatlah penting, mulai dari ketersediaan air di dalam rumah, hingga perubahan cuaca suatu wilayah. Aliran fluida nampak bergerak acak, hal itu karena keterbatasan alat dan pengetahuan untuk mengamati hal tersebut. Fluida adalah zat yang berubah bentuk secara terus-menerus ketika dikenakan oleh tegangan geser sebesar apa pun [4][5][6]. Semua analisa yang berhubungan dengan gerakan fluida didasarkan atas prinsip prinsip alam yang bersifat dasar yaitu: (1) Hukum Kekekalan Massa, (2) Hukum Newton yang kedua, (3) Hukum Termodinamika yang pertama. Hukum Newton yang kedua merupakan dasar asas kesetimbangan momentum, sedangkan hukum termodinamika yang pertama merupakan prinsip kekekalan energi [7][8][9].

Persamaan Navier-Stokes merupakan persamaan yang disajikan dalam bentuk berpasangan yang menjelaskan pergerakan suatu fluida baik cairan maupun gas[10]. Persamaan - persamaan ini menyatakan bahwa perubahan momentum partikel fluida bergantung pada gaya gesek(viskositas) yang bekerja pada fluida[11]. Dengan kata lain persamaan Navier-Stokes menjelaskan kesetimbangan gayagaya yang bekerja pada fluida[12]. Persamaan Navier-Stokes merupakan sistem persamaan diferensial pasial nonlinier orde dua yang kompleks dengan memiliki satu atau lebih turunan-turunan parsial [13]. Persamaan Navier-Stokes sering kali digunakan para peneliti di Badan Meteorologi, Klimatologi dan Geofisika (BMKG) untuk meramalkan keadaan alam terutama pada aliran fluida di atmosfer [14]. Pergerakan fluida di atmosfer tentu sangat kompleks, dibutuhkan model yang sesuai untuk menggambarkan pergerakan dari fluida tersebut.

Fluida adalah zat yang berubah bentuk secara terus-menerus ketika dikenakan oleh tegangan geser sebesar apa pun [4]. Dalam mengamati fluida, peneliti memusatkan perhatiannya pada bentuk infinitesimal fluida yang memiliki luas permukaan yang sama disetiap arah permukaanya. Yaitu paketpaket fluida berupa kubus yang memiliki enam permukaan pada tiga arah normalnya. Tegangan geser adalah tegangan pada arah tangensial permukaan suatu material sedangkan tegangan yang bekerja pada arah normal disebut tegangan normal. Beberapa sifat fluida yang selalu menjadi kuantitas penting dalam pembahasan fluida adalah densitas, tekanan, velositas dan viskositas. Desnaitas adalah massa jenis fluida. Tekanan adalah tingkat kompresi suatu fluida yang dapat mengakibatkan perubahan volume fluida. Perubahan volume akan memepengaruhi besaran dari densitas fluida. Fluida yang ketika mengalir densitasnya tidak berubah maka fluida tersebut termasuk dalam golongan fluida yang tidak termampatkan. Velositas adalah kecepatan fluida, velositas merupakan besaran vektor, sehingga arah dari kecepatan merupakan hal yang selalu dipertimbangkan. Viskositas adalah koefisien kekentalan fluida, yaitu ketahanan fluida terhadap aliran. Semakin besar nilai viskositas maka semakin susah fluida tersebut untuk mengalir. Fluida Newtonian adalah uida yang besaran tegangan gesernya bergantung secara linear dengan gradien velositas. Fluida yang tergabung dalam kelompok memenuhi persamaan berikut:

$$
s_{j i}=\mu \frac{\partial u_{i}}{\partial x_{j}}
$$

dimana $\boldsymbol{s}$ adalah tegangan geser, $\boldsymbol{u}$ adalah velositas, $\boldsymbol{x}$ adalah koordinat ruang dan $\mu$ adalah koefisien viskositas. Secara sederhana dapat dipahami bahwa fluida Newtonian akan mudah sekali untuk mengalir jika dikenakan tegangan geser sekecil apapun, contoh: air, madu, minyak. Sedangkan fluida Non-Newtonian memiliki suatu titik dimana dia tidak akan mengalir meskipun dikenakan gaya geser dengan kekuatan tertentu, contohnya mayonnaise [15].

Pada artikel ini, pembahasan pemodelan persamaan Navier-Stokes dibatasi pada fluida Newtonian dan aliran fluida yang tidak termampatkan. Selanjtumya, persamaan Navier-Stokes diturunkan dari hokum-hukum dasar fisika. Yaitu Hukum Newton kedua dan hukum kekekalan massa. Hukum Newton II menyatakan bahwa Kecepatan suatu objek adalah berbanding lurus terhadap gaya 
yang berkerja padanya, dan berbanding terbalik terhadap masa objek tersebut[16]. Menggunakan pernyataan matematika, Hukum Newton II dapat ditulis sebagai berikut:

$$
\sum F=m a
$$

Dimana $F$ adalah gaya yang bekerja pada objek, $m$ adalah massa objek dan $a$ adalah percepatan objek. Momentum adalah perkalian antara massa dan kecepatan[16]. Jika kita subtitusikan percepatan sebagai perubahan kecepatan terhadap waktu sebagai berikut:

$$
\begin{aligned}
& \sum F=m \frac{d \boldsymbol{u}}{d \boldsymbol{t}}, \\
& \sum F=\frac{d m \boldsymbol{u}}{d \boldsymbol{t}} .
\end{aligned}
$$

Berdasarkan hasil ini, hukum Newton dua juga dinyatakan sebagai berikut: perubahan momentum persatuan waktu suatu objek sama dengan resultan gaya yang bekerja pada objek [17]. Hukum ini juga sering disebut sebagai hukum kesetimbangan momentum.

Beberapa konsep dalam matematika diaplikasikan dalam pemodelan ini, diantaranya adalah vektor, tensor, persamaan diferensial dan metode beda hingga skema eksplisit[18]. Vektor merupakan besaran yang memiliki arah. Biasanya sering direpresentasikan dengan bentuk panah. Panjang panah adalah besar vektor, dan arah dari panah tersebut merepresentasikan arah vektor[19]. Dalam teori vektor terdapat beberapa hal yang dapat diturunkan. Antara lain gradient laplacian dan divergensi vektor. Gradien merupakan turunan total pertama dari suatu fungsi baik itu scalar maupun vektor. Laplacian adalah turunan pertama dari gradient. Sedangkan divergensi adalah jumlah dari turunan parsial total pertamanya. Divergensi ini juga disebut sebagai densitas fluks. Fluks adalah banyaknya kuantitas fluida yang melewati suatu satuan ruang per satuan waktu. Densitas fluks merupakan turunan pertama fluks terhadap ruang[20][21]. Pergerakan aliran fluida digambarkan dalam bentuk vektor vektor dalam suatu domain terbuka. Pengamatan difokuskan dalam suatu ruang domain dan bayangkan fluida masuk dan keluar melewati domain tersebut. Teorema divergensi menyatakan bahwa fluks yang berada dalam volume $V$ sama dengan fluks yang keluar melalui permukaan $S$ untuk suatu volume $V$ yang diselubungi permukaan $S$. Teorema divergensi dituliskan sebagai berikut:

Teorema 1: (Teorema Divergensi)

Andaikan $F=M \boldsymbol{i}+N \boldsymbol{j}+P \boldsymbol{k}$ berupa medan vektor, sedemikian sehingga $M, N$, dan $Q$ mempunyai turunan parsial pertama yang kontinu pada domain $\Omega$ dan batasnya $\partial \Omega$. Jika $\boldsymbol{n}$ menyatakan vektor normal satuan terhadap $\Omega$, maka

$$
\iint_{\partial \Omega} \boldsymbol{F} \cdot \boldsymbol{n} d S=\iiint \iiint_{\Omega} \nabla \cdot F d \boldsymbol{x}
$$

Aliran fluida yang tidak termampatkan secara sederhana dapat dipahami bahwa ketika fluida mengalir melewati suatu domain, maka jumlah fluida yang masuk ke domain tersebut akan selalu sama dengan fluida yang keluar dari domain tersebut. Secara formal, fakta ini dituliskan dalam sebuah teorema yang dikenal dengan teorema Transport.

Teorema 2: (Teorema Transport)

Misalkan $\boldsymbol{u}(\boldsymbol{x}, t)$ adalah medan vektor $C^{2}$ pada domain $\Omega$ yang parallel terhadap $\partial \Omega$, dengan aliran $\Phi(\boldsymbol{x}, t)$. $\Phi$ adalah fungsi kontinu dan terdiferensial yang merupakan pemetaan partikel fluida $\boldsymbol{x}$, misalkan $f(\boldsymbol{x}, t)$ adalah fungsi yang kontinu dan terdiferensial pada domain $\Omega$, maka:

$$
\frac{d}{d t} \int_{\Omega_{\mathrm{t}}} f d \boldsymbol{x}=\int_{\Omega_{\mathrm{t}}} \frac{\partial}{\partial t} f+\operatorname{div}(f \boldsymbol{u}) d \boldsymbol{x}
$$

[23].

Persamaan Navier-Stoke merupakan persamaan dalam bentuk persamaan diferensial parsial, karena kuantitas - kuantitas dalam fluida sepeti velositas dan tekanan tidak hanya berubah terhadap waktu namun juga berubah terhadap ruang. Untuk mendeskripsikan fenomena tegangan normal dan 
geser diperlukan teori tensor. Jika vektor merupakan besaran yang memiliki dua unsur yaitu besaran dan arah maka tensor merupakan besaran secara umum. Bisa memiliki sebanyak $n$ unsur. Sehingga, besaran scalar dikatakan sebagai tensor orde nol, vektor adalah tensor orde satu dan seterusnya. Pada kasus tensor tegangan. Tensor yang digunakan adalah tensor orde dua.

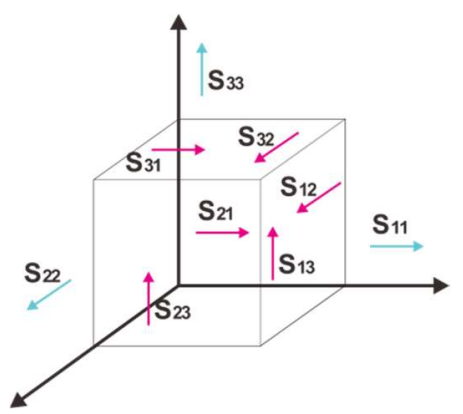

Gambar 1. Representasi Tegangan pada Suatu Infinitesimal Fluida

Tensor ini dituliskan dalam bentuk matriks $3 \times 3$ sebagai berikut:

$$
\left(\begin{array}{lll}
S_{11} & s_{12} & S_{13} \\
S_{21} & S_{22} & S_{23} \\
S_{31} & S_{32} & S_{33}
\end{array}\right)
$$

Dimana $s_{11}, s_{22}, s_{33}$ adalah tegangan pada arah normal dan selain daripada itu adalah tegangan geser.

Solusi dari persamaan Navier-Stokes masih menjadi misteri hingga kini. Bahkan eksistensi dan ketunggaalan dari solusinya saja masih belum dapat dibuktikan secara analisis. Solusi aproksimasi menjadi pendekatan yang telah diterapkan oleh banyak peneliti di dunia dewasa ini. Salah satu metode yang paling mudah dan terkenal adalah metode beda hingga. Yaitu bentuk diferensial pada suatu persamaan dituliskan dalam didekati melalui persamaan yang diturunkan dari definisi limit. Domain fluida pada awalnya didiskritisasi menjadi titik-titik berhingga. Bentuk diskritisasi dari suatu domain fluida berupa titik-titik dengan jarak yang sama seperti ditunjukkan pada gambar berikut:

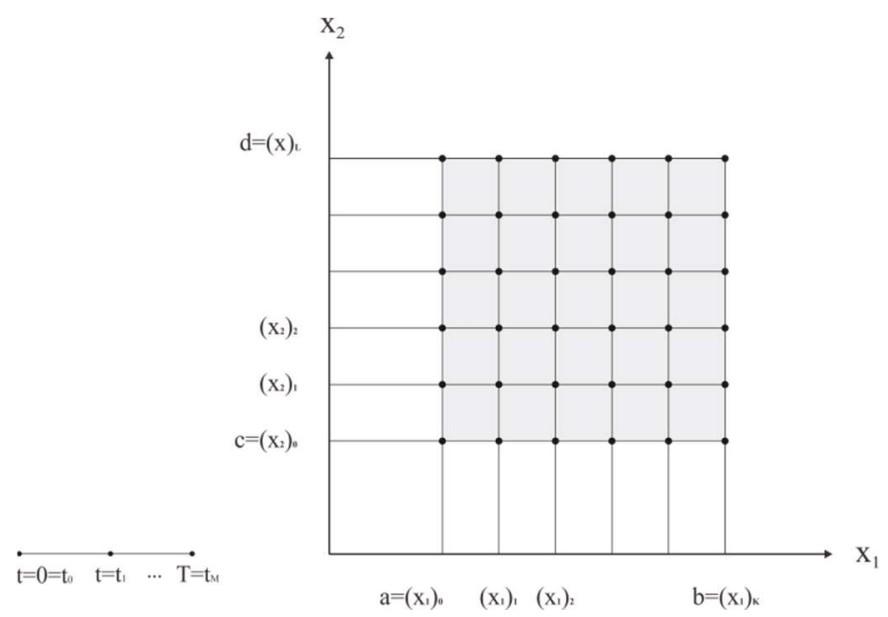

Gambar 2. Diskritisasi Domain Ruang dan Waktu.

Nilai suatu fungsi di titik-titik grid pada gambar 2 merupakan pada saat $t$ didekati oleh hasil aproksimasi fungsi tersebut di titik yang sama pada waktu $t$, dapat dituliskan sebagai berikut:

$$
(f)_{i, j}^{m} \approx f\left(t_{m},\left(x_{1}\right)_{i},\left(x_{2}\right)_{j}\right) .
$$


Berdasarkan definisi limit:

$$
\left(\frac{\partial f}{\partial x_{1}}\right)_{\left(t_{m},\left(x_{1}\right)_{i},\left(x_{2}\right)_{j}\right)}=\lim _{\Delta x_{1} \rightarrow 0} \frac{f\left(\left(x_{1}\right)_{i}+\Delta x\right)-f\left(\left(x_{1}\right)_{i}\right)}{\Delta x_{1}} .
$$

Kemudian tiga aproksimasi standar untuk turunan pertama $\frac{\partial f}{\partial x_{1}}$ adalah:

(Selisih Mundur)

$$
\left(\frac{\partial f}{\partial x_{1}}\right)_{\left(t_{m},\left(x_{1}\right)_{i},\left(x_{2}\right)_{j}\right)} \approx \lim _{\Delta x_{1} \rightarrow 0} \frac{f_{i, j}^{m}-f_{i-1, j}^{m}}{\Delta x_{1}} .
$$

(Selisih Maju)

$$
\left(\frac{\partial f}{\partial x_{1}}\right)_{\left(t_{m},\left(x_{1}\right)_{i},\left(x_{2}\right)_{j}\right)} \approx \lim _{\Delta x_{1} \rightarrow 0} \frac{f_{i+1, j}^{m}-f_{i, j}^{m}}{\Delta x_{1}} .
$$

(Selisih Terpusat)

$$
\left(\frac{\partial f}{\partial x_{1}}\right)_{\left(t_{m},\left(x_{1}\right)_{i},\left(x_{2}\right)_{j}\right)} \approx \lim _{\Delta x_{1} \rightarrow 0} \frac{f_{i+1, j}^{m}-f_{i-1, j}^{m}}{\Delta x_{1}} .
$$

\section{METODE}

Metode yang digunakan pada penelitian ini adalah studi pustaka. Teori-teori dasar mekanika fluida, kalkulus vektor dan persamaaan diferensial merupakan sumber utama yang dikaji terlebih dahulu sebelum melakukan pembahasan pemodelan persamaan Navier-Stokes untuk aliran fluida tidak termampatkan. Kajian persamaan Navier-Stokes ini dikembangkan melalui penggabungan beberapa sumber pustaka dan memberikan uraian-uraian untuk lebih memahami konsep dari persamaan ini. Setelah dipahami proses persamaan dan pemodelan dari persamaan Navier-Stokes ini dilakukan suatu simulasi numerik pada kasus aliran dalam rongga. Metode yang digunakan adalah beda hingga skema eksplisit. Simulasi menggunakan software MATLAB, dan ditampilkan secara grafis.

\section{HASIL DAN PEMBAHASAN}

Misal pada saat $=0$, fluida mengisi domain terbuka terbatas $\Omega_{0}$ dengan batas $\partial \Omega_{0}$. Anggap setiap titik $\boldsymbol{a} \in \Omega_{0}$ sebagai partikel fluida yang bergerak saat $t>0$. Posisi saat $t$ dituliskan sebagai fungsi $\Phi(\boldsymbol{a}, t)$. Pada waktu tersebut elemen fluida menempati domain:

$$
\Omega_{t}=\left\{\Phi(\boldsymbol{a}, t): \boldsymbol{a} \in \Omega_{0}\right\}
$$

Kurva $t \rightarrow \Phi(\boldsymbol{a}, t)$, mendeskripsikan lintasan partikel fluida yang dimulai dari $t=0$ dengan koordinat awal $\boldsymbol{a}=\Phi(\boldsymbol{a}, 0)$. Domain, partikel dan lintasan gerak partikel fluida diasumsikan memenuhi asumsi berikut:

Asumsi 3:

Terdapat fungsi kontinu dan terdiferensial $\Phi(\boldsymbol{a}, t)$ dengan sifat-sifat berikut:

$$
\begin{array}{ll}
\text { 1. } & \Phi(\boldsymbol{a}, 0)=\boldsymbol{a} \\
\text { 2. } & \text { Jika } \boldsymbol{a} \neq \boldsymbol{b} \text { maka } \Phi(\boldsymbol{a}, t) \neq \Phi(\boldsymbol{b}, t) \text { untuk } t \geq 0 \\
\text { 3. } & \text { Pemetaan } \boldsymbol{a} \rightarrow \Phi(\boldsymbol{a}, t) \text { memiliki invers yang kontinu dan terdiferensial. }
\end{array}
$$

[11].

Selanjutnya, misalkan vektor dimensi tiga $\boldsymbol{u}(\boldsymbol{x}, t)$ dituliskan sebagai velositas dari suatu aliran fluida di $\boldsymbol{x} \in \Omega_{t}$ saat maka 


$$
\boldsymbol{u}(\boldsymbol{x}, t)=\frac{\partial \Phi(\boldsymbol{a}, t)}{\partial t}=\Phi^{\prime}(\boldsymbol{a}, t), \quad \text { Jika } \boldsymbol{x}=\Phi(\boldsymbol{a}, t)
$$

Kemudian, percepatan merupakan turunan pertama dari velositas atau turunan kedua dari fungsi $\Phi(\boldsymbol{a}, t)$ yaitu $\Phi^{\prime \prime}(\boldsymbol{a}, t)$. Menggunakan notasi turunan parsial percepatan dapat dituliskan sebagai berikut:

$$
\boldsymbol{a}(t)=\boldsymbol{u}_{t}+u_{1} \boldsymbol{u}_{x_{1}}+u_{2} \boldsymbol{u}_{x_{2}}+u_{3} \boldsymbol{u}_{x_{3}}
$$

Dimana $u_{i}=\frac{d x_{i}}{d t}, u_{x_{i}}=\frac{\partial u}{\partial x_{i}}$, dengan $i=1,2,3$. Menggunakan notasi vektor persamaan (1) dapat dituliskan sebagai berikut:

$$
\boldsymbol{a}(t)=\boldsymbol{u}_{t}+\boldsymbol{u} \cdot \nabla \boldsymbol{u}
$$

Persamaan (2) disebut sebagai persamaan derivatif material. Persamaan ini tidak hanya untuk percepatan saja, namun untuk turunan kedua semua fungsi pada kuantitas-kuantitas yang dibahas dalam fluida seperti densitas, suhu dan lain sebagainya. Secara umum persamaan derivatif material didefinisikan sebagai berikut:

\section{Definisi 4:}

Misalkan $f(\boldsymbol{x}, t)$ adalah fungsi kontinu di dalam domain $\Omega$ yang menyatakan kuantitas fluida seperti densitas, velositas dan suhu. Perubahan fungsi kuantitas tersebut terhadap waktu adalah

$$
\frac{D}{D t} f(\boldsymbol{x}, t)=\frac{\partial}{\partial t} f(\boldsymbol{x}, t)+\boldsymbol{u} \cdot \nabla \boldsymbol{f}
$$

Dimana operator $D /$ Dt disebut sebagai operator derivatif material.

Sifat-sifat fluida yang selalu menjadi topik pembahasan adalah densitas dan massa fluida. keduanya dihubungkan melalui definisi berikut:

\section{Definisi 5:}

Untukt $t \geq 0$ didefinisikan fungsi kontinu dan terdiferensial $\rho=\rho(\boldsymbol{x}, t) \geq 0$ untuk setiap domain fluida $\Omega_{t}$. Fungsi $\rho=\rho(\boldsymbol{x}, t)$ disebut sebagai densitas fluida, kemudian massa dari domain fluida $\Omega_{t}$ adalah

[6]

$$
m(\Omega, t)=\int_{\Omega_{t}} \rho(\boldsymbol{x}, t) d \boldsymbol{x}
$$

Hukum kekekalan massa menyatakan bahwa massa tidak bias diciptakan atau dimusnahkan, atau dengan kata lain massa tidak pernah berubah. Hukum ini diasumsikan selalu dipenuhi oleh fluida, sehingga disusun asumsi berikut yang merupakan asumsi untuk hukum kekekalan massa.

\section{Asumsi 6:}

Terdapat fungsi kontinu dan terdiferensial $\rho=\rho(\boldsymbol{x}, t)$ untuk setiap domain fluida $\Omega_{t}$ yang disebut sebagai densitas fluida untuk $t \geq 0$

$$
\int_{\Omega_{t}} \rho(\boldsymbol{x}, t) d \boldsymbol{x}=\int_{\Omega_{0}} \rho(\boldsymbol{x}, 0) d \boldsymbol{x}
$$

[11]

Asumsi ini menyatakan bahwa massa tetap atau tidak berubah terhadap waktu. Misal $\boldsymbol{n}$ adalah vektor normal satuan di setiap titik pada batas $\partial \Omega$. Misal $d A$ adalah luas permukaan $\partial \Omega$.

Laju volume uida yang melewati $\partial \boldsymbol{\Omega}$ per satuan luas adalah $\boldsymbol{u} \cdot \boldsymbol{n}$ dan laju massa uida per satuan luas adalah $\rho . \boldsymbol{u} \cdot \boldsymbol{n}$. Hal ini diliustrasikan pada gambar 3 berikut: 


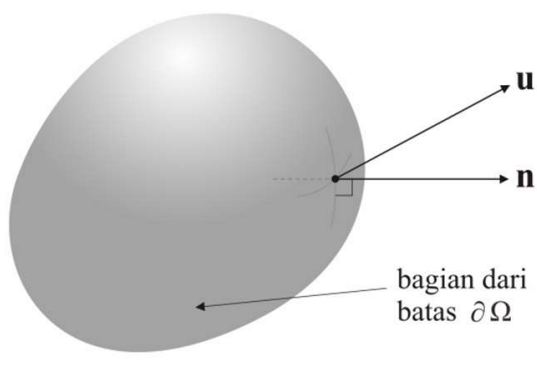

Gambar 3. Laju Massa per Satuan Luas sama dengan Nilai dari Integral Permukaan $\rho . u \cdot n$.

Seperti yang ditunjukkan pada gambar 3, prinsip dari kekekalan massa sesungguhnya juga dapat dinyatakan sebagai berikut: "Laju peningkatan massa yang berada di dalam $\Omega t$ adalah sama dengan laju massa yang masuk(arah ke dalam) melalui batas $\partial \Omega t$ "(Chorin dan Marsden, 2000: 3). Secara matematis dapat ditulis sebagai berikut:

$$
\frac{d}{d t} \int_{\Omega_{\mathrm{t}}} \rho d \boldsymbol{x}=-\int_{\partial \Omega_{\mathrm{t}}} \boldsymbol{\rho u} \cdot \boldsymbol{n d} \boldsymbol{A}
$$

Persamaan (3) merupakan bentuk integral dari hukum kekekalan massa. Jika diaplikasikan teorema divergensi pada persamaan ini, maka persamaan (3) ekuivalen dengan

$$
\int_{\Omega_{\mathrm{t}}}\left[\frac{\partial \rho}{\partial t}+\operatorname{div} \rho \boldsymbol{u}\right] d \boldsymbol{x}=0 .
$$

Karena integrand diterapkan diseluruh $\Omega t$, maka tanda integral dapat dihilangkan sebagai berikut:

$$
\frac{\partial \rho}{\partial t}+\operatorname{div} \rho \boldsymbol{u}=0
$$

Persamaan (4) biasa disebut dengan persamaan kontinuitas yang sesungguhnya merupakan bentuk deferensial dari hukum kekekalan massa. Jika $\rho$ dan $\boldsymbol{u}$ tidak cukup kontinu dan terdiferensial untuk diterapkan operasi-operasi deferensial dalam hukum kekekalan massa maka bentuk integral dapat dipergunakan. Pada kasus fluida yang tak termampatkan, tidak adanya tekanan membuat tidak adanya perubahan volume dan massa fluida. Akibatnya densitas uida tidak mengalami perubahan atau konstan. Untuk kasus ini maka persamaan kontinuitas menjadi sebagai berikut:

$$
\operatorname{div} \boldsymbol{u}=0 .
$$

Momentum fluida di dalam domain $\Omega_{t}$ adalah

$$
\int_{\Omega_{t}} \rho(\boldsymbol{x}, t) \boldsymbol{u}(\boldsymbol{x}, t) d \boldsymbol{x} .
$$

Berdasarkan Hukum Newton ke-dua, perubahan momentum terhadap waktu sama dengan gaya yang bekerja pada besaran massa di dalam domain $\Omega t$. Asumsikan bahwa gaya ini merupakan jumlahan dari gaya - gaya eksternal di luar elemen fluida (misalnya gravitasi, gaya Coriolis, atau gaya 
elektromagnetik) dan gaya internal, yang bekerja pada batas domain fluida. Gaya internal disebabkan gesekan antar elemen fluida. Kita asumsikan hal ini dapat ditulis dalam bentuk medan tensor tegangan sebagai berikut:

\section{Asumsi 5:}

Terdapat medan gaya $\boldsymbol{F}=\boldsymbol{F}(\boldsymbol{x}, t)$ dan medan tensor tegangan

$$
\boldsymbol{S}=\boldsymbol{S}(\boldsymbol{x}, t)=\left(\begin{array}{l}
\boldsymbol{s}_{1} \\
\boldsymbol{s}_{2} \\
\boldsymbol{s}_{3}
\end{array}\right)=\left(\begin{array}{lll}
s_{11} & s_{12} & s_{13} \\
s_{21} & s_{22} & s_{23} \\
s_{31} & s_{32} & s_{33}
\end{array}\right)
$$

Sedemikian sehingga, untuk setiap domain $\Omega_{t}$

$$
\frac{d}{d t} \int_{\Omega_{t}} \rho(\boldsymbol{x}, t) \boldsymbol{u}(\boldsymbol{x}, t) d \boldsymbol{x}=\int_{\Omega_{t}} \rho(\boldsymbol{x}, t) \boldsymbol{F}(\boldsymbol{x}, t) d \boldsymbol{x}+\int_{\partial \Omega_{t}} \boldsymbol{S}(\boldsymbol{x}, t) \boldsymbol{n}(\boldsymbol{x}, t) d \boldsymbol{x}
$$

[11].

Bentuk $\frac{d}{d t} \int_{\Omega_{t}} \rho(\boldsymbol{x}, t) \boldsymbol{u}(\boldsymbol{x}, t) d \boldsymbol{x}$ di bagian kiri persamaan (5) adalah menuliskan perubahan momentum fluida. Bentuk $\int_{\Omega_{t}} \rho(\boldsymbol{x}, t) \boldsymbol{F}(\boldsymbol{x}, t) d \boldsymbol{x}$ adalah gaya eksternal yang bekerja pada fluida disetiap titik dalam domain fluida. Gaya internal fluida disebabkan oleh pergerakan partikel-partikel fluida. Untuk memahami hal ini, akan disajikan situasi seperti gambar 4 Medan velositas $\boldsymbol{u}$ paralel terhadap permukaan $E$ tapi mengalami perubahan besaran sesaat setelah melewati permukaan $E$. Jika semua gaya normal terhadap $E$, maka tidak terdapat transfer momentum antara sejumlah volume fluida $B$ dan $B$ '. Bagaimanapun, menurut teori kinetika material, hal ini tidak mungkin terjadi. Partikel-partikel yang lebih cepat yang berada di atas permukaan $E$ akan terdifusi melewati permukaan $E$ dan menghasilkan momentum terhadap fluida di bawahnya. Sebaliknya, partikel-partikel yang lebih pelan di bawah $E$ akan terdifusi melewati $E$ dan memperlambat aliran fluida di atasnya. Sehingga, gaya per satuan luas pada permukaan domain dinyatakan dalam bentuk $\int_{\partial \Omega_{t}} \boldsymbol{S}(\boldsymbol{x}, t) \boldsymbol{n}(\boldsymbol{x}, t) d \boldsymbol{x}$ (Chorin dan Marsden: 2000: 32).

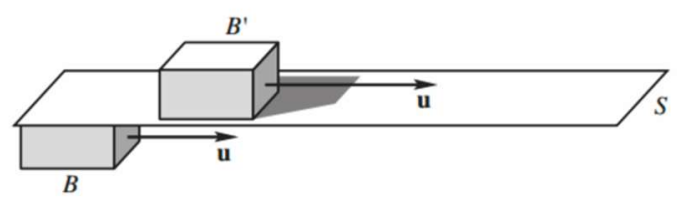

Gambar 4. Molekul yang Lebih Cepat B' Terdifusi melewati E dan Menghasilkan Momentum terhadap B

Persamaan (5) dituliskan dalam notasi vektor, sehingga menggunakan teorema Divergensi, kita peroleh:

$$
\begin{gathered}
\int_{\partial \Omega_{\mathrm{t}}} \boldsymbol{S n} d \boldsymbol{x}=\int_{\Omega_{\mathrm{t}}} \operatorname{div} \boldsymbol{S} d \boldsymbol{x} \\
\operatorname{div} \boldsymbol{S}=\left(\begin{array}{ll}
\operatorname{div} & \boldsymbol{s}_{1} \\
\operatorname{div} & \boldsymbol{s}_{2} \\
\operatorname{div} & \boldsymbol{s}_{3}
\end{array}\right) .
\end{gathered}
$$

Jika kita terapkan teorema Transport untuk sisi kiri persamaan (5) akan diperoleh:

$$
\int_{\Omega_{t}}\left\{\frac{D}{D t}(\rho \boldsymbol{u})+\rho \boldsymbol{u} \operatorname{div} \boldsymbol{u}-\rho \boldsymbol{F}-\operatorname{div} \boldsymbol{S}\right\} d \boldsymbol{x}=0
$$

Selama asumsi 3 dipenuhi, tanda integral dapat dihilangkan. Kemudian subtitusikan persamaan kontinuitas div $\boldsymbol{u}$, diperoleh 


$$
\rho \frac{D}{D t} \boldsymbol{u}=\rho \boldsymbol{F}+\operatorname{div} \boldsymbol{S}
$$

Persamaan (6) disebut sebagai persamaan momentum [11].

Analisis lebih lanjut dari gerakan fluida tergantung pada pengetahuan tentang tensor tegangan $\boldsymbol{S}$. Kita harus menghubungkan tensor $\boldsymbol{S}$ ke variabel aliran lainnya. Pada kasus yang inviscid, diasumsikan tidak ada tegangan geser akibatnya hanya terdapat gaya normal di tiga arah pada koordinat kartesius. Didefinisikan sebagai berikut:

\section{Definisi 6:}

Suatu aliran dikatakan inviscid (tidak kental sama sekali) jika tensor tegangan $\boldsymbol{S}$ adalah sebagai berikut:

$$
\boldsymbol{S}(\boldsymbol{x}, t)=-p(\boldsymbol{x}, t)\left(\begin{array}{lll}
1 & 0 & 0 \\
0 & 1 & 0 \\
0 & 0 & 1
\end{array}\right)=-p(\boldsymbol{x}, t) I
$$

[11].

Berdasar definisi 17, selanjutnya kita akan membahas kasus fluida yang kental, yang membutuhkan bentuk yang lebih umum dari tensor tegangan $\boldsymbol{S}$ pada persamaan (7). Ketergantungan $\boldsymbol{S}$ yang tepat pada variabel aliran lainnya hanya dapat disimpulkan dari percobaan lebih lanjut. Jika gerakannya seragam, yaitu, jika gradien kecepatan nol di setiap titik, maka eksperimen menunjukkan bahwa bentuk sederhana (7) untuk $\boldsymbol{S}$ masih dipenuhi.

Dengan demikian, cukup beralasan untuk mengasumsikan bahwa $\boldsymbol{S}+p \boldsymbol{I}$ bergantung secara linier pada matriks gradien velositas:

Dimana

$$
\boldsymbol{S}=-p \boldsymbol{I}+\tilde{S}(T), \quad \tilde{S} \text { linear pada } T
$$

$$
T=T(\boldsymbol{x}, t)=\left(\begin{array}{lll}
\frac{\partial u_{1}}{\partial x_{1}} & \frac{\partial u_{1}}{\partial x_{2}} & \frac{\partial u_{1}}{\partial x_{3}} \\
\frac{\partial u_{2}}{\partial x_{1}} & \frac{\partial u_{2}}{\partial x_{2}} & \frac{\partial u_{2}}{\partial x_{3}} \\
\frac{\partial u_{3}}{\partial x_{1}} & \frac{\partial u_{3}}{\partial x_{2}} & \frac{\partial u_{3}}{\partial x_{3}}
\end{array}\right)
$$

Selanjutnya, $\boldsymbol{S}$ hanya bergantung pada bagian simetris dari $T$, yaitu pada tensor deformasi

$$
D=\frac{1}{2}\left(T+T^{*}\right),
$$

dan bukan pada rotasi lokal fluida yang dijelaskan oleh bagian antisimetris $\frac{1}{2}\left(T+T^{*}\right)$ dari $T$.

Berdasarkan percobaan Couette berikut:

\section{Percobaan Couette:}

Pada percobaan ini, sebuah tabung diisi oleh fluida. Kemudian tabung ini diputar terhadap porosnya. Bagian luar dari tabung akan ikut berputar mengikuti putaran dari fluida. Situasi ini diilustrasikan pada gambar 5. Setelah beberapa saat, bagian luar dan fluida bergerak dengan kecepatan yang sama seperti pada bagian poros tabung. Dengan demikian, gerakan ini sama halnya gerakan rotasi pada benda padat, yaitu tidak terdapat transfer momentum lagi sehingga kita peroleh $\boldsymbol{S}=-\boldsymbol{p} I$. Matriks $T$ yang sesuai untuk rotasi benda padat bersifat antisimetri. Oleh karena itu, masuk akal untuk mengasumsikan bahwa $\boldsymbol{S}$ adalah nol untuk argumen antisimmetri dan bergantung pada bagian simetris $\frac{1}{2}\left(T+T^{*}\right)$ dari T saja. 


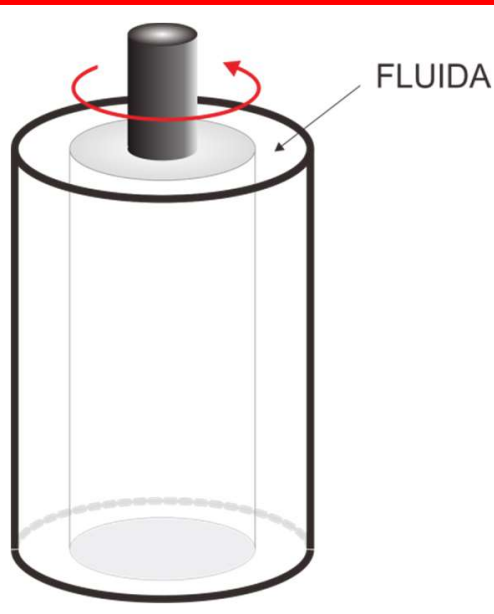

Gambar 5. Percobaan Couette

Berdasar percobaan Couette ini, kita memiliki argumen kuat untuk mengatakan bahwa tensor tegangan $\boldsymbol{S}$ hanya bergantung pada bagian simteris dari $T$ yaitu $D=\frac{1}{2}\left(T+T^{*}\right)$, dimana bentuk $T^{*}$ adalah transpose dari tensor $T$, dapat dituliskan sebagai berikut:

$$
\begin{array}{r}
D=\frac{1}{2}\left(\left[\begin{array}{lll}
\frac{\partial u_{1}}{\partial x_{1}} & \frac{\partial u_{1}}{\partial x_{2}} & \frac{\partial u_{1}}{\partial x_{3}} \\
\frac{\partial u_{2}}{\partial x_{1}} & \frac{\partial u_{2}}{\partial x_{2}} & \frac{\partial u_{2}}{\partial x_{3}} \\
\frac{\partial u_{3}}{\partial x_{1}} & \frac{\partial u_{3}}{\partial x_{2}} & \frac{\partial u_{3}}{\partial x_{3}}
\end{array}\right]+\left[\begin{array}{lll}
\frac{\partial u_{1}}{\partial x_{1}} & \frac{\partial u_{2}}{\partial x_{1}} & \frac{\partial u_{3}}{\partial x_{1}} \\
\frac{\partial u_{1}}{\partial x_{2}} & \frac{\partial u_{2}}{\partial x_{2}} & \frac{\partial u_{3}}{\partial x_{2}} \\
\frac{\partial u_{1}}{\partial x_{3}} & \frac{\partial u_{2}}{\partial x_{3}} & \frac{\partial u_{3}}{\partial x_{3}}
\end{array}\right]\right) \\
=\frac{1}{2}\left(\begin{array}{ccc}
2 \frac{\partial u_{1}}{\partial x_{1}} & \frac{\partial u_{1}}{\partial x_{2}}+\frac{\partial u_{2}}{\partial x_{1}} & \frac{\partial u_{1}}{\partial x_{3}}+\frac{\partial u_{3}}{\partial x_{1}} \\
\frac{\partial u_{1}}{\partial x_{2}}+\frac{\partial u_{2}}{\partial x_{1}} & 2 \frac{\partial u_{2}}{\partial x_{2}} & \frac{\partial u_{2}}{\partial x_{3}}+\frac{\partial u_{3}}{\partial x_{2}} \\
\frac{\partial u_{1}}{\partial x_{3}}+\frac{\partial u_{3}}{\partial x_{1}} & \frac{\partial u_{2}}{\partial x_{3}}+\frac{\partial u_{3}}{\partial x_{2}} & 2 \frac{\partial u_{3}}{\partial x_{3}}
\end{array}\right)
\end{array}
$$

Teorema 7:

Jika $\tilde{S}=\tilde{S}(D)$ adalah fungsi linear dari D yang tidak berubah dalam semua rotasi dari sistem koordinat, maka

$$
\tilde{S}\left(U D U^{*}\right)=U \tilde{S}(D) U^{*}
$$

Untuk semua matriks orthogonal $3 \times 3$ Udan semua matriks simetri $3 \times 3$ D. Kemudian $\tilde{S}$ dapat ditulis sebagai:

$$
\tilde{S}(D)=\mu^{\prime}\left(d_{11}+d_{22}+d_{33}\right) I+2 \mu D,
$$

dimana $\mu$ dan $\mu^{\prime}$ adalah konstanta yang independen terhadap D [11].

Sehingga diperoleh tensor tegangan sebagai berikut:

$$
\boldsymbol{S}=-p \boldsymbol{I}+\mu^{\prime} \operatorname{div} u \boldsymbol{I}+\mu\left(T+T^{*}\right) .
$$

Mengingat sifat fluida yang tidak termampatkan $(\operatorname{div} \boldsymbol{u}=0)$, maka kita peroleh: 


$$
\boldsymbol{S}=\left(\begin{array}{ccc}
-p & 0 & 0 \\
0 & -p & 0 \\
0 & 0 & -p
\end{array}\right)+\mu\left(\begin{array}{ccc}
2 \frac{\partial u_{1}}{\partial x_{1}} & \frac{\partial u_{1}}{\partial x_{2}}+\frac{\partial u_{2}}{\partial x_{1}} & \frac{\partial u_{1}}{\partial x_{3}}+\frac{\partial u_{3}}{\partial x_{1}} \\
\frac{\partial u_{1}}{\partial x_{2}}+\frac{\partial u_{2}}{\partial x_{1}} & 2 \frac{\partial u_{2}}{\partial x_{2}} & \frac{\partial u_{2}}{\partial x_{3}}+\frac{\partial u_{3}}{\partial x_{2}} \\
\frac{\partial u_{1}}{\partial x_{3}}+\frac{\partial u_{3}}{\partial x_{1}} & \frac{\partial u_{2}}{\partial x_{3}}+\frac{\partial u_{3}}{\partial x_{2}} & 2 \frac{\partial u_{3}}{\partial x_{3}}
\end{array}\right)
$$
berikut:

Jika kita subtitusikan persamaan ini ke dalam persamaan momentum (6) diperoleh sebagai

$$
\frac{\partial \boldsymbol{u}}{\partial t}+\boldsymbol{u} \cdot \nabla \boldsymbol{u}=\boldsymbol{F}-\frac{1}{\rho} \nabla p+\frac{\mu}{\rho} \Delta \boldsymbol{u} .
$$

Jika kita sandingkan persamaan ini dengan persamaan kontinuitas maka diperoleh:

$$
\begin{aligned}
\frac{\partial \boldsymbol{u}}{\partial t}+\boldsymbol{u} \cdot \nabla \boldsymbol{u}=\boldsymbol{F} & -\frac{1}{\rho} \nabla p+\frac{\mu}{\rho} \Delta \boldsymbol{u} . \\
\operatorname{div} \boldsymbol{u} & =0
\end{aligned}
$$

Sistem persamaan ini disebut sebagai persamaan Navier-Stokes untuk fluida yang tidak termampatkan. Sedangkan sistem persamaan Navier-Stokes pada dimensi dua adalah sebagai berikut:

$$
\begin{gathered}
\rho\left(\frac{\partial u_{1}}{\partial t}+u_{1} \frac{\partial u_{1}}{\partial x_{1}}+u_{2} \frac{\partial u_{1}}{\partial x_{2}}\right)=F_{1}-\frac{\partial p}{\partial x_{1}}+\mu\left(\frac{\partial^{2} u_{1}}{\partial^{2}\left(x_{1}\right)^{2}}+\frac{\partial^{2} u_{1}}{\partial^{2}\left(x_{2}\right)^{2}}\right), \\
\rho\left(\frac{\partial u_{2}}{\partial t}+u_{1} \frac{\partial u_{2}}{\partial x_{1}}+u_{2} \frac{\partial u_{2}}{\partial x_{2}}\right)=F_{2}-\frac{\partial p}{\partial x_{2}}+\mu\left(\frac{\partial^{2} u_{2}}{\partial^{2}\left(x_{1}\right)^{2}}+\frac{\partial^{2} u_{2}}{\partial^{2}\left(x_{2}\right)^{2}}\right), \\
\frac{\partial u_{1}}{\partial x_{1}}+\frac{\partial u_{2}}{\partial x_{2}}=0 .
\end{gathered}
$$

Setelah diperoleh sistem persamaan Navier-Stokes (11),(12) dan (13), langkah selanjutnya adalah untuk mensimulasikan persamaan ini. Tentu kita akan mensimulasikan solusi dari persamaan ini. Yaitu velositas $\boldsymbol{u}$ dan tekanan $p$ harus diperoleh. Sebelum kita aplikasikan metode untuk menemukan solusi numeriknya, kita akan memodifikasi system persamaan terakhir agar dapat dicari solusinya. Sistem persamaan yang ada, adalah system dengan tiga persamaan dengan tiga variabel yang tidak diketahui yaitu $p, u_{1}$ dan $u_{2}$. Namun, pada persamaan (13), tidak terdapat variabel $p$ disana. Dengan menggantikan persamaan (13) menggunakan persamaan lain yang memenuhi prinsip kontinuitas, maka persamaan ini dapat dipecahkan, dengan syarat persamaan ini memuat ketiga variabel tersebut. Salah satu caranya adalah menggantikan persamaan kontinuitas dengan persamaan Poisson untuk tekanan yang diperoleh dari divergensi persamaan momentum (11) dan (12). Sehingga sistem persamaan Navier-Stokes menjadi:

$$
\begin{gathered}
\rho\left(\frac{\partial u_{1}}{\partial t}+u_{1} \frac{\partial u_{1}}{\partial x_{1}}+u_{2} \frac{\partial u_{1}}{\partial x_{2}}\right)=F_{1}-\frac{\partial p}{\partial x_{1}}+\mu\left(\frac{\partial^{2} u_{1}}{\partial^{2}\left(x_{1}\right)^{2}}+\frac{\partial^{2} u_{1}}{\partial^{2}\left(x_{2}\right)^{2}}\right), \\
\rho\left(\frac{\partial u_{2}}{\partial t}+u_{1} \frac{\partial u_{2}}{\partial x_{1}}+u_{2} \frac{\partial u_{2}}{\partial x_{2}}\right)=F_{2}-\frac{\partial p}{\partial x_{2}}+\mu\left(\frac{\partial^{2} u_{2}}{\partial^{2}\left(x_{1}\right)^{2}}+\frac{\partial^{2} u_{2}}{\partial^{2}\left(x_{2}\right)^{2}}\right) \\
\frac{\partial^{2} p}{\partial\left(x_{1}\right)^{2}}+\frac{\partial^{2} p}{\partial\left(x_{2}\right)^{2}}=-\rho\left[\frac{\partial}{\partial t}\left(\frac{\partial u_{1}}{\partial x_{1}}+\frac{\partial u_{2}}{\partial x_{2}}\right)+\left(\frac{\partial u_{1}}{\partial x_{1}}\right)^{2}+2\left(\frac{\partial u_{1}}{\partial x_{2}} \frac{\partial u_{2}}{\partial x_{1}}\right)+\left(\frac{\partial u_{2}}{\partial x_{2}}\right)^{2}\right] .
\end{gathered}
$$


Sistem persamaan ini, sudah bisa kita selesaikan atau kita hitung aproksimasi solusinya, karena terdiri atas tiga persamaan dengan tiga variabel yang tidak diketahui. Aproksimasi solusi ini diterapkan pada kasus aliran di dalam rongga.

Aliran di dalam rongga yang dimaksud berupa rongga yang disusun oleh suatu persegi atau kotak tertutup dengan ukuran tertentu sperti ditunjukkan pada gambar 6 Sisi-sisi tersebut menjadi pembatas fluida, sehingga kecepatan fluida di setiap sisi sama dengan nol. Untuk menunjukkan aliran fluida dalam rongga tersebut ketika dikenakan gaya geser. Maka pada sisi atas pada arah $u_{1}$ diberikan suatu nilai kecepatan konstan. Setelah itu akan dihitung velositas dan tekanan selanjutnya hingga pada waktu tertentu $t_{m}$.

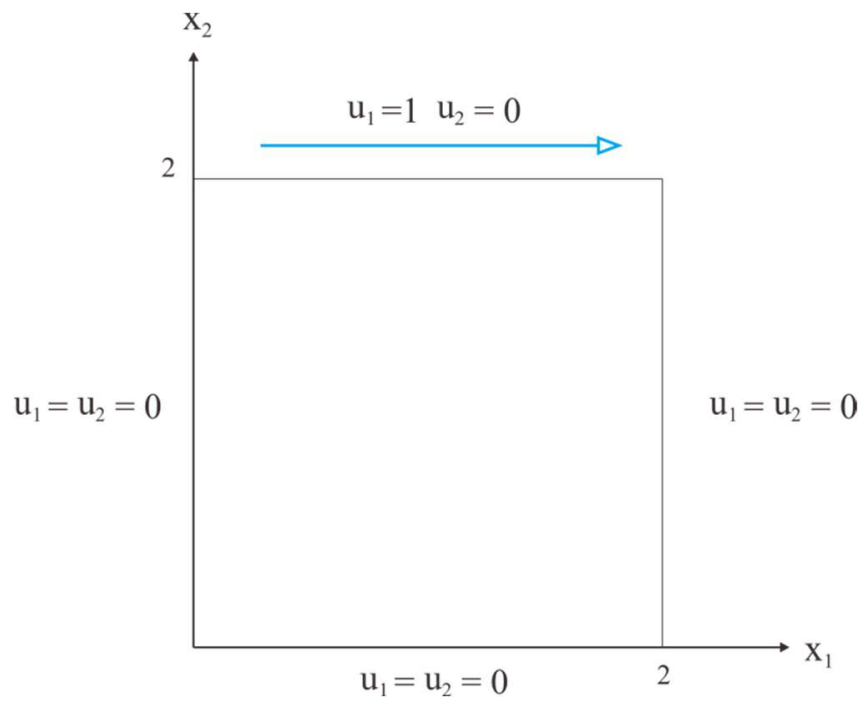

Gambar 6. Ilustrasi Domain Aliran Rongga

Untuk menghitung velositas dan tekanan. Sebelumnya akan dilakukan diskretisasi domain. Berikut hasil diskretisasi domain pada kasus aliran dalam rongga.

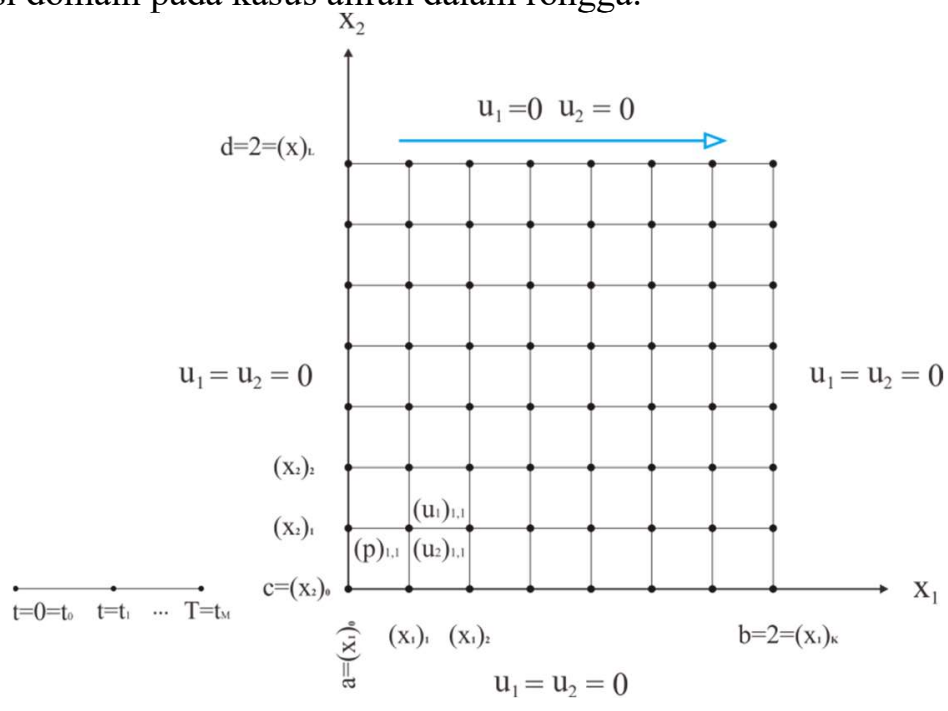

Gambar 7. Ilustrasi Diskretisasi Domain Aliran Rongga

Persamaan Navier-Stokes didiskretisasi menggunakan metode beda hingga. Didefinisikan aproksimasi dari $\boldsymbol{u}$ dan $p$ pada diskretisasi domain tersebut. Antara lain sebagai berikut:

$$
\left(u_{1}\right)_{i, j}^{m} \approx u_{1}\left(t_{m},\left(x_{1}\right)_{i},\left(x_{2}\right)_{j}\right)
$$




$$
\begin{gathered}
\left(u_{2}\right)_{i, j}^{m} \approx u_{2}\left(t_{m},\left(x_{1}\right)_{i},\left(x_{2}\right)_{j}\right), \\
p_{i, j}^{m} \approx u_{1}\left(t_{m},\left(x_{1}\right)_{i},\left(x_{2}\right)_{j}\right) .
\end{gathered}
$$

Pada persamaan Navier-Stokes, perubahan velositas dan tekanan terhadap waktu dan ruang diaproksimasi menggunakan metode beda hingga sebagai berikut:

1. Menggunakan metode beda hingga selisih maju orde satu, perubahan $u_{1}$ dan $u_{2}$ terhadap $t$ adalah sebagai berikut:

$$
\begin{aligned}
& \left(\frac{\partial u_{1}}{\partial t}\right)_{\left(t_{m},\left(x_{1}\right)_{i},\left(x_{2}\right)_{j}\right)}=\frac{u_{1}\left(t_{m+1},\left(x_{1}\right)_{i},\left(x_{2}\right)_{j}\right)-u_{1}\left(t_{m},\left(x_{1}\right)_{i},\left(x_{2}\right)_{j}\right)}{t_{m+1}-t_{m}}, \\
& \left(\frac{\partial u_{2}}{\partial t}\right)_{\left(t_{m},\left(x_{1}\right)_{i},\left(x_{2}\right)_{j}\right)}=\frac{u_{2}\left(t_{m+1},\left(x_{1}\right)_{i},\left(x_{2}\right)_{j}\right)-u_{2}\left(t_{m},\left(x_{1}\right)_{i},\left(x_{2}\right)_{j}\right)}{t_{m+1}-t_{m}} .
\end{aligned}
$$

2. Perubahan $u_{1}, u_{2}$ terhadap $x_{1}$ dan $x_{2}$ pada bentuk $\nabla \boldsymbol{u}$ menggunakan selisih mundur orde satu:

$$
\begin{aligned}
& \left(\frac{\partial u_{1}}{\partial x_{1}}\right)_{\left(t_{m},\left(x_{1}\right)_{i},\left(x_{2}\right)_{j}\right)}=\frac{\left(u_{1}\right)_{i, j}^{m}-\left(u_{1}\right)_{i-1, j}^{m}}{\Delta x_{1}}, \\
& \left(\frac{\partial u_{1}}{\partial x_{2}}\right)_{\left(t_{m},\left(x_{1}\right)_{i},\left(x_{2}\right)_{j}\right)}=\frac{\left(u_{1}\right)_{i, j}^{m}-\left(u_{1}\right)_{i, j-1}^{m}}{\Delta x_{2}}, \\
& \left(\frac{\partial u_{2}}{\partial x_{1}}\right)_{\left(t_{m},\left(x_{1}\right)_{i},\left(x_{2}\right)_{j}\right)}=\frac{\left(u_{2}\right)_{i, j}^{m}-\left(u_{2}\right)_{i-1, j}^{m}}{\Delta x_{1}}, \\
& \left(\frac{\partial u_{2}}{\partial x_{2}}\right)_{\left(t_{m},\left(x_{1}\right)_{i},\left(x_{2}\right)_{j}\right)}=\frac{\left(u_{2}\right)_{i, j}^{m}-\left(u_{2}\right)_{i, j-1}^{m}}{\Delta x_{2}} .
\end{aligned}
$$

3. Perubahan tekanan $p$ terhadap $x_{1}$ dan $x_{2}$ menggunakan selisih terpusat orde satu yaitu:

$$
\begin{aligned}
& \left(\frac{\partial p}{\partial x_{1}}\right)_{\left(t_{m},\left(x_{1}\right)_{i},\left(x_{2}\right)_{j}\right)}=\frac{p_{i+1, j}^{m}-p_{i-1, j}^{m}}{2 \Delta x_{1}}, \\
& \left(\frac{\partial p}{\partial x_{2}}\right)_{\left(t_{m},\left(x_{1}\right)_{i},\left(x_{2}\right)_{j}\right)}=\frac{p_{i, j+1}^{m}-p_{i, j-1}^{m}}{2 \Delta x_{2}} .
\end{aligned}
$$

4. Perubahan $u_{1}, u_{2}$ terhadap $x_{1}$ dan $x_{2}$ pada bentuk $\Delta \boldsymbol{u}$ menggunakan selisih terpusat orde dua yaitu:

$$
\begin{aligned}
& \left(\frac{\partial^{2} u_{1}}{\partial\left(x_{1}\right)^{2}}\right)_{\left(t_{m},\left(x_{1}\right)_{i},\left(x_{2}\right)_{j}\right)}=\frac{\left(u_{1}\right)_{i+1, j}^{m}-2\left(u_{1}\right)_{i, j}^{m}+\left(u_{1}\right)_{i-1, j}^{m}}{\left(\Delta x_{1}\right)^{2}}, \\
& \left(\frac{\partial^{2} u_{1}}{\partial\left(x_{1}\right)^{2}}\right)_{\left(t_{m},\left(x_{1}\right)_{i},\left(x_{2}\right)_{j}\right)}=\frac{\left(u_{1}\right)_{i, j+1}^{m}-2\left(u_{1}\right)_{i, j}^{m}+\left(u_{1}\right)_{i, j-1}^{m}}{\left(\Delta x_{1}\right)^{2}}, \\
& \left(\frac{\partial^{2} u_{2}}{\partial\left(x_{1}\right)^{2}}\right)_{\left(t_{m},\left(x_{1}\right)_{i},\left(x_{2}\right)_{j}\right)}=\frac{\left(u_{2}\right)_{i+1, j}^{m}-2\left(u_{2}\right)_{i, j}^{m}+\left(u_{2}\right)_{i-1, j}^{m}}{\left(\Delta x_{1}\right)^{2}}, \\
& \left(\frac{\partial^{2} u_{2}}{\partial\left(x_{2}\right)^{2}}\right)_{\left(t_{m},\left(x_{1}\right)_{i},\left(x_{2}\right)_{j}\right)}=\frac{\left(u_{2}\right)_{i, j+1}^{m}-2\left(u_{2}\right)_{i, j}^{m}+\left(u_{2}\right)_{i, j-1}^{m}}{\left(\Delta x_{2}\right)^{2}} .
\end{aligned}
$$


5 .

Pada persamaan Poisson untuk tekanan, yang menggantikan persamaan kontinuitas, perubahan terhadap ruang diaproksimasi denganmetode selisih terpusat orde dua sebagai berikut:

$$
\begin{aligned}
& \left(\frac{\partial p}{\partial\left(x_{1}\right)^{2}}\right)_{\left(t_{m},\left(x_{1}\right)_{i},\left(x_{2}\right)_{j}\right)}=\frac{p_{i+1, j}^{m}-2 p_{i, j}^{m}+p_{i-1, j}^{m}}{\left(\Delta x_{1}\right)^{2}}, \\
& \left(\frac{\partial p}{\partial\left(x_{2}\right)^{2}}\right)_{\left(t_{m},\left(x_{1}\right)_{i},\left(x_{2}\right)_{j}\right)}=\frac{p_{i, j+1}^{m}-2 p_{i, j}^{m}+p_{i, j-1}^{m}}{\left(\Delta x_{2}\right)^{2}} .
\end{aligned}
$$

6. Perubahan velositas terhadap ruang pada persamaan Poisson untuk tekanan menggunakan metode slisih terpusat orde satu sebagai berikut:

$$
\begin{aligned}
& \left(\frac{\partial u_{1}}{\partial x_{1}}\right)_{\left(t_{m},\left(x_{1}\right)_{i},\left(x_{2}\right)_{j}\right)}=\frac{\left(u_{1}\right)_{i+1, j}^{m}-\left(u_{1}\right)_{i-1, j}^{m}}{2 \Delta x_{1}}, \\
& \left(\frac{\partial u_{1}}{\partial x_{2}}\right)_{\left(t_{m},\left(x_{1}\right)_{i},\left(x_{2}\right)_{j}\right)}=\frac{\left(u_{1}\right)_{i, j+1}^{m}-\left(u_{1}\right)_{i, j-1}^{m}}{2 \Delta x_{2}}, \\
& \left(\frac{\partial u_{2}}{\partial x_{1}}\right)_{\left(t_{m},\left(x_{1}\right)_{i},\left(x_{2}\right)_{j}\right)}=\frac{\left(u_{2}\right)_{i+1, j}^{m}-\left(u_{2}\right)_{i-1, j}^{m}}{2 \Delta x_{1}}, \\
& \left(\frac{\partial u_{2}}{\partial x_{2}}\right)_{\left(t_{m},\left(x_{1}\right)_{i},\left(x_{2}\right)_{j}\right)}=\frac{\left(u_{2}\right)_{i, j+1}^{m}-\left(u_{2}\right)_{i, j-1}^{m}}{2 \Delta x_{2}} .
\end{aligned}
$$

Dari masing-masing diskretisasi tersebut, kemudian kita subtitusikan ke dalam persamaan Navier-Stokes yang kemudian menghasilkan persamaan diskret Navier-Stokes. Setelah mendapatkan persamaan diskret Navier-Stokes kemudian kita peroleh persamaan rekursif untuk masing-masing variabel sebagai berikut:

1. Persamaan diskret rekursif untuk komponen $u_{1}$

$$
\begin{aligned}
& \left(u_{1}\right)_{i, j}^{m+1}=\left(u_{1}\right)_{i, j}^{m}-\left(u_{1}\right)_{i, j}^{m}\left(\frac{\Delta t}{\Delta x_{1}}\right)\left(\left(u_{1}\right)_{i, j}^{m}-\left(u_{1}\right)_{i-1, j}^{m}\right) \\
& -\left(u_{2}\right)_{i, j}^{m}\left(\frac{\Delta t}{\Delta x_{2}}\right)\left(\left(u_{1}\right)_{i, j}^{m}-\left(u_{1}\right)_{i, j-1}^{m}\right) \\
& -\left(\frac{\Delta t}{2 \rho \Delta x_{1}}\right)\left((p)_{i+1, j}^{m}-(p)_{i-1, j}^{m}\right) \\
& +\frac{\mu}{\rho}\left[\begin{array}{c}
\left(\frac{\Delta t}{\left(\Delta x_{1}\right)^{2}}\right)\left(\left(u_{1}\right)_{i+1, j}^{m}-2\left(u_{1}\right)_{i, j}^{m}+\left(u_{1}\right)_{i-1, j}^{m}\right) \\
+\left(\frac{\Delta t}{\left(\Delta x_{2}\right)^{2}}\right)\left(\left(u_{1}\right)_{i, j+1}^{m}-2\left(u_{1}\right)_{i, j}^{m}+\left(u_{1}\right)_{i, j+1}^{m}\right)
\end{array}\right]
\end{aligned}
$$

2. Persamaan diskret rekursif untuk komponen $u_{2}$

$$
\begin{aligned}
\left(u_{2}\right)_{i, j}^{m+1}=\left(u_{2}\right)_{i, j}^{m} & -\left(u_{1}\right)_{i, j}^{m}\left(\frac{\Delta t}{\Delta x_{1}}\right)\left(\left(u_{2}\right)_{i, j}^{m}-\left(u_{2}\right)_{i-1, j}^{m}\right) \\
& -\left(u_{2}\right)_{i, j}^{m}\left(\frac{\Delta t}{\Delta x_{2}}\right)\left(\left(u_{2}\right)_{i, j}^{m}-\left(u_{2}\right)_{i, j-1}^{m}\right) \\
& -\left(\frac{\Delta t}{2 \rho \Delta x_{2}}\right)\left((p)_{i+1, j}^{m}-(p)_{i-1, j}^{m}\right)
\end{aligned}
$$




$$
+\frac{\mu}{\rho}\left[\begin{array}{c}
\left(\frac{\Delta t}{\left(\Delta x_{1}\right)^{2}}\right)\left(\left(u_{2}\right)_{i+1, j}^{m}-2\left(u_{2}\right)_{i, j}^{m}+\left(u_{2}\right)_{i-1, j}^{m}\right) \\
+\left(\frac{\Delta t}{\left(\Delta x_{2}\right)^{2}}\right)\left(\left(u_{2}\right)_{i, j+1}^{m}-2\left(u_{2}\right)_{i, j}^{m}+\left(u_{2}\right)_{i, j+1}^{m}\right)
\end{array}\right]
$$

3. Persamaan diskret rekursif untuk $p$

$$
\begin{aligned}
p_{i, j}^{m} & =\frac{\left(\Delta x_{2}\right)^{2}}{2\left(\left(\Delta x_{2}\right)^{2}+\left(\Delta x_{2}\right)^{2}\right)}\left(p_{i+1, j}^{m}-p_{i-1, j}^{m}\right) \\
& +\frac{\left(\Delta x_{2}\right)^{2}}{2\left(\left(\Delta x_{2}\right)^{2}+\left(\Delta x_{2}\right)^{2}\right)}\left(p_{i, j+1}^{m}-p_{i, j-1}^{m}\right) \\
& -\frac{\left(\Delta x_{1}\right)^{2}\left(\Delta x_{2}\right)^{2}}{2\left(\left(\Delta x_{2}\right)^{2}+\left(\Delta x_{2}\right)^{2}\right)} \rho\left[\begin{array}{c}
{\left[\frac{1}{\Delta t}\left(\left(\frac{\left(u_{1}\right)_{i+1, j}^{m}-\left(u_{1}\right)_{i-1, j}^{m}}{2 \Delta x_{1}}\right)+\left(\frac{\left(u_{2}\right)_{i, j+1}^{m}-\left(u_{2}\right)_{i, j-1}^{m}}{2 \Delta x_{2}}\right)\right)\right]} \\
-\left(\frac{\left(u_{1}\right)_{i+1, j}^{m}-\left(u_{1}\right)_{i-1, j}^{m}}{\Delta x_{1}}\right)^{2} \\
-2-\left(\frac{\left(u_{1}\right)_{i, j+1}^{m}-\left(u_{1}\right)_{i, j-1}^{m}}{\Delta x_{2}}\right)\left(\frac{\left(u_{2}\right)_{i+1, j}^{m}-\left(u_{2}\right)_{i-1, j}^{m}}{\Delta x_{1}}\right) \\
-\left(\frac{\left(u_{2}\right)_{i, j+1}^{m}-\left(u_{2}\right)_{i, j-1}^{m}}{\Delta x_{2}}\right)^{2}
\end{array}\right]
\end{aligned}
$$

Karena kita langsung memodifikasi persamaan Navier-Stokes dalam bentuk eksplisitnya, maka skema ini disebut sebagai skema eksplisit.

Nilai awal sistem persamaan pada kasus aliran rongga adalah $p, u_{1}, u_{2}=0$ dimanapun, sedangan syarat batas adalah:

$$
\begin{aligned}
& u_{1}=1 \text { saat } x_{2}=2 ; \\
& u_{1}, u_{2}=0 \text { pada batas yang lain; } \\
& \frac{\partial p}{\partial x_{2}}=0 \text { saat } x_{2}=0 ; \\
& p=0 \text { saat } x_{2}=0 ; \\
& \frac{\partial p}{\partial x_{1}}=0 \text { saat } x_{1}=0 \text { dan } x_{1}=2 .
\end{aligned}
$$

Penyusunan m-file untuk simulasi di dasarkan pada algoritma berikut:

Algoritma 8: [Simulasi aliran rongga (Cavity Flow)]

- diberikan jumlah titik untuk diskretisasi domain, banyaknya titik $x_{1}, x_{2}$ dan $t$

- diberikan titik awal dan titik akhir interval domain untuk $x_{1}$ dan $x_{2}$

- diberikan nilai konstanta untuk $\rho, \mu$ dan panjang interval perubahan waktu $\Delta t$

- menentukan titik-titik grid

- diberikan nilai awal untuk $u_{1}, u_{2}$ dan $p$.

- menghitung matriks $p$

- menerapkan syarat batas untuk $p$

- menghitung matriks $u_{1}$ dan $u_{2}$

- menerapkan syarat batas untuk $u_{1}$ dan $u_{2}$

- plot hasil untuk $t$ terakhir

Pada simulasi ini, diberikan input sebagai berikut:

1. Jumlah titik pada arah $x_{1}=21$.

2. Jumlah titik pada arah $x_{2}=21$.

3. Jumlah titik waktu $t=50$. 
4. Jumlah iterasi untuk menghitung tekanan adalah 100.

5. Nilai viskositas $=0.1$.

6. Nilai densitas $=1$.

7. Interval baik $x_{1}$ dan $x_{2}$ adalah 0 sampai 2 .

8. Panjang interval waktu $d t=0.01$

Hasil dari m-file ini adalah sebagai berikut:

1. Surface plot dan Contour plot dari komponen vektor $u_{1}$
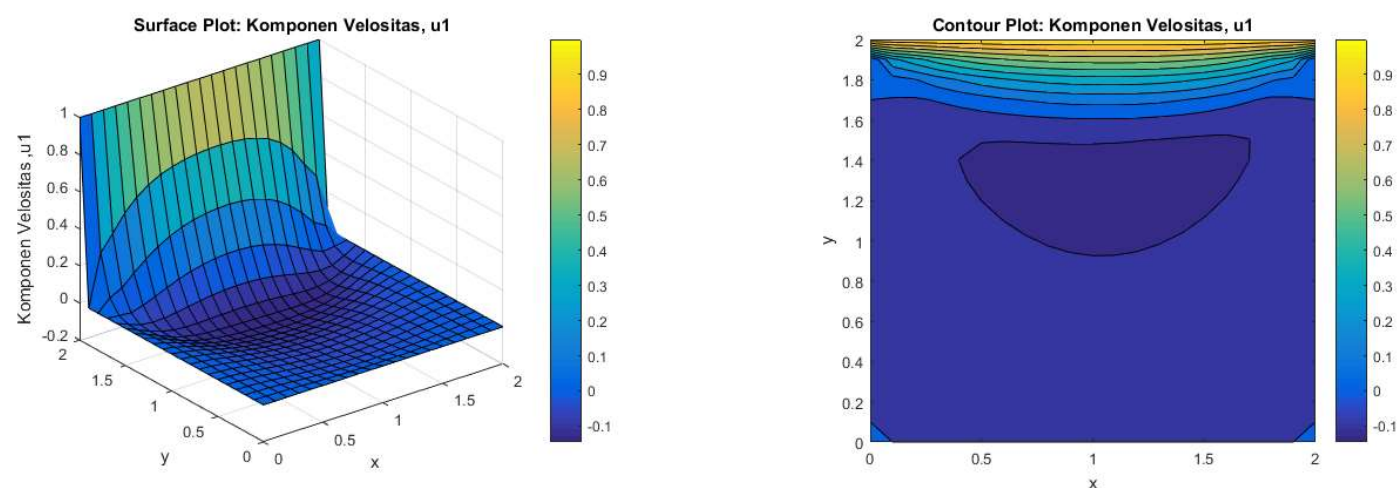

Gambar 8. Komponen Vektor Velositas $u_{1}$

Pada arah $u_{1}$, terlihat kecepatan terus menurun dari nilai awal $u 1$ yang telah diberikan yaitu $u_{1}=1$. Berdasarkan gambar 8 kita dapat melihat pola penurunan kecepatan pada komponen $u_{1}$ yang turun hingga nilai minimum sebesar $-0,1$. Tanda negatif menunjukkan arah yang berlawanan.

2. Surface plot dan Contour plot dari komponen vektor $u_{2}$.
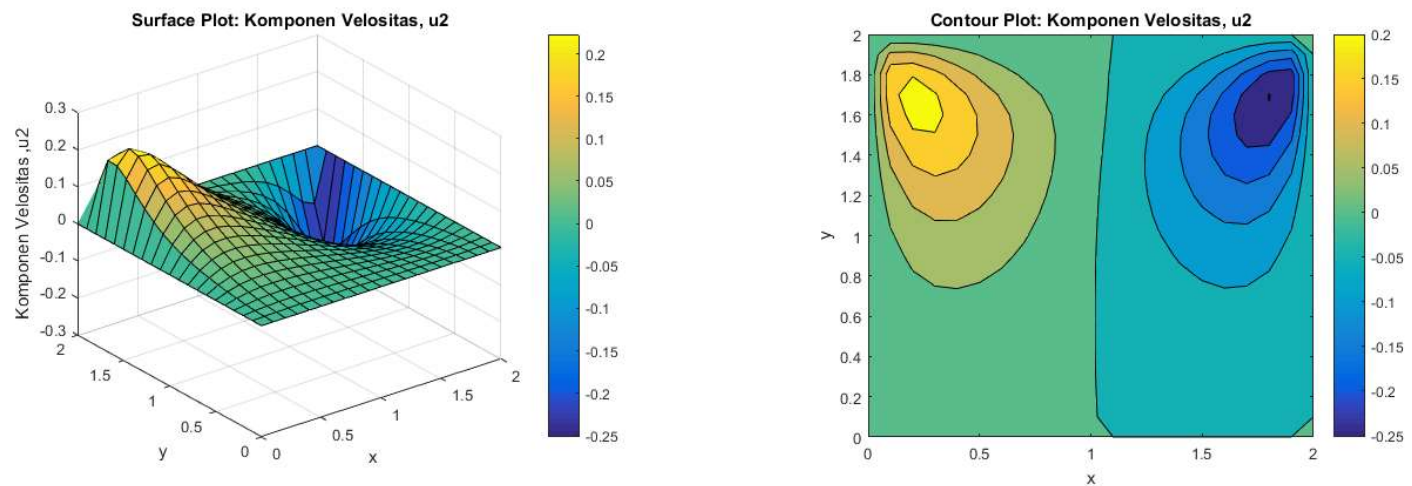

Gambar 9. Komponen Vektor Velositas $u_{2}$.

Gerakan yang disebabkan oleh kecepatan pada arah $u_{1}$ yaitu nilai awal $u_{1}=1$, menyebabkan perubahan kecepatan seperti ditunjukkan pada gambar 9. Kecepatan tertinggi pada arah $u_{2}$ adalah 0.2 dan kecepatan terendah adalah -0.25 . Tanda negatif menunjukkan arah yang berlawanan.

3. Surface plot dan Contour plot dari tekanan $p$. 
Jurnal Ilmiah Matematika, 6 (1), 2019 - 38

Joko Eliyanto, Julan Hernadi
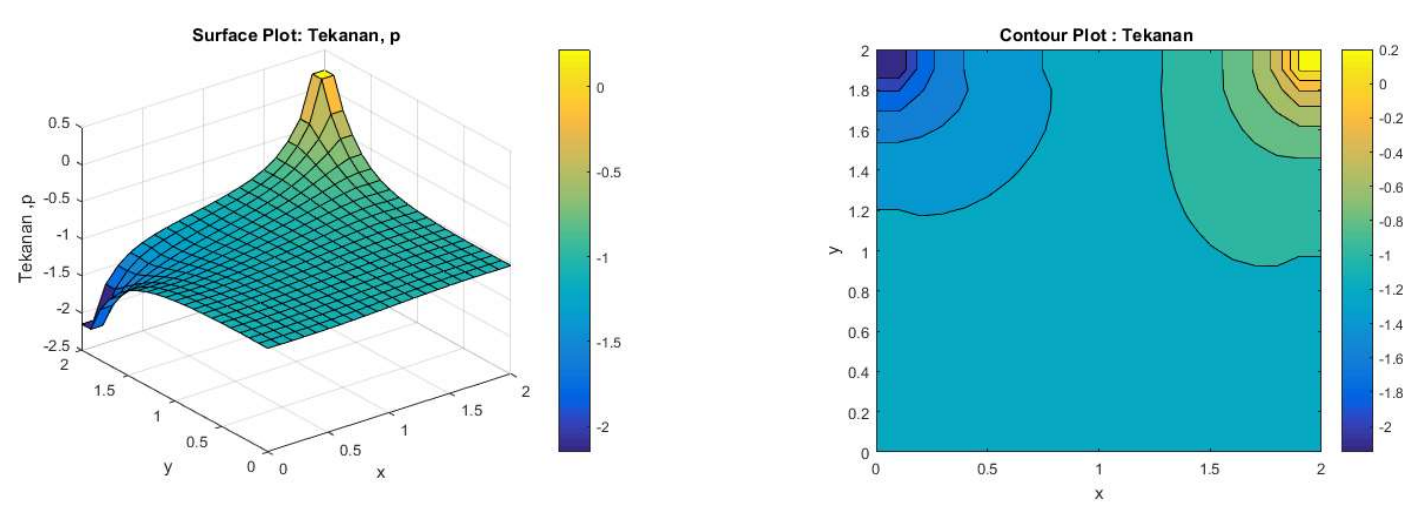

Gambar 10. Tekanan $p$.

Berdasarkan gambar 10, tekanan di sisi kiri atas domain bertanda negatif karena terdapat gaya yang masuk ke dalam domain, fluida mengalir ke ujung domain dan menabrak dinding domain sebelah kanan sehingga ada tekanan yang mengarah keluar sehingga tekanan bertanda positif. Hal tersebut terus terjadi hingga pada bagian bawah domain tekanan menjadi seragam karena gradien velositas di sana juga semakin kecil.

1. Vector plot dari medan vektor velositas $\boldsymbol{u}$.

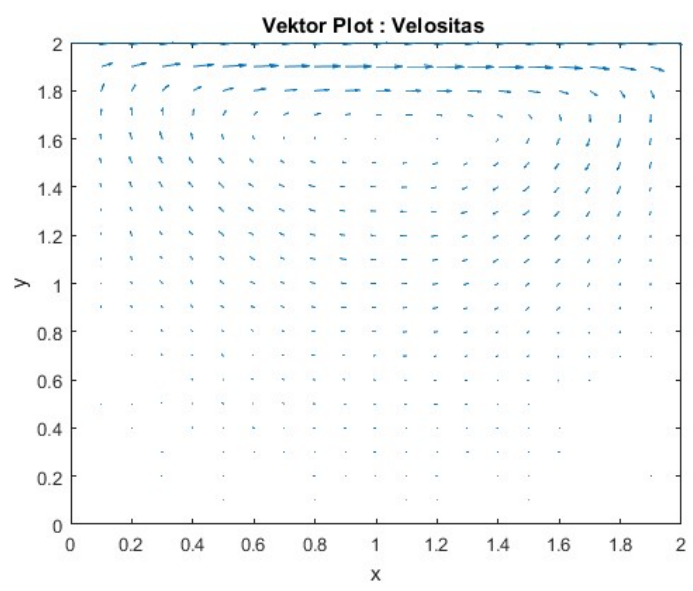

Gambar 11. Medan Vektor $\boldsymbol{u}$.

Berdasar hasil plot pada gambar 11, dapat dilihat aliran fluida menuju pusat pusaran, besaran velositas terus mengecil menuju pusat pusaran. Medan vektor yang dihasilkan oleh simulasi ini sesuai dengan aliran fluida pada kasus yang sama pada percobaan-percobaan aliran dalam rongga yang pernah dilakukan.

\section{SIMPULAN}

Persamaan Navier-Stoke merupakan persamaan yang memodelkan aliran fluida. Persamaan Navier-Stokes pada ruang dimensi dua merupakan system persamaan diferensial parsial nonlinear orde dua yang terdiri dari persamaan kontinuitas dan dua persamaan momentum. Persamaanpersamaan ini dimodelkan berdasarkan dua prinsip dasar alam yaitu hukum kekekalan massa yang kemudian dimodelkan dalam persamaan kontinuitas dan hukum kesetimbangan momentum yang dimodelkan dalam dua persamaan momentum. Hubungan antara velositas fluida, tekanan dan viskositas tergambar pada tensor tegangan $\boldsymbol{S}$. Kemudian, solusi aproksimasi persamaan ini dapat ditemukan menggunakan metode beda hingga skema eksplisit. Skema eksplisit lebih mudah diterapkan daripada skema eksplisit karena kita hanya memodifikasi persamaan yang ada. Simulasi pada kasus aliran dalam rongga dalam persegi tertutup menunjukkan bahwa persamaan ini mampu memodelkan gerakan fluida dengan cukup baik. 


\section{DAFTAR PUSTAKA}

[1] D. R. E. C. Rahmad, D. S. E. Ikawati, S. SI, and Y. W. Syaifudin, Metode Numerik: Metode Numerik, vol. 1. UPT Percetakan dan Penerbitan Polinema, 2018.

[2] R. L. Burden and D. J. Faires, "Numerical analysis," 1985.

[3] J. N. Kapur, Mathematical models in biology and medicine. Affiliated East-West Press, 1985.

[4] B. R. Munson, D. F. Young, T. H. Okiishi, and W. W. Huebsch, "Fundamentals of Fluid Mechanics, John Wiley \& Sons," Inc., USA, 2006.

[5] R. Aris, "Vectors, Tensors and the Basic Equations of Fluid Mechanics (Dover Books on Mathematics)."

[6] Y. A. Cenqel and J. M. Cimbala, "Fluid-Mechanics-fundamentals-and-applications-2thedition." McGraw-Hill Science/Engineering/Math, 2004.

[7] H. Djojodihardjo, "Mekanika Fluida," Jakarta: Erlangga, 1983.

[8] A. Ghurri, "Dasar-Dasar Mekanika Fluida," Bukit Jimbaran Jur. Tek. Mesin Univ. Udayana, 2014.

[9] A. J. Chorin, J. E. Marsden, and J. E. Marsden, A mathematical introduction to fluid mechanics, vol. 175. Springer, 1990.

[10] P. G. Lemarié-Rieusset, The Navier-Stokes problem in the 21st century. CRC Press, 2018.

[11] M. Frank, "White," Fluid Mechanics", McGraw Hill," 2011.

[12] C. Pozrikidis, Fluid dynamics: theory, computation, and numerical simulation. Springer, 2016.

[13] C. A. Hapsoro and W. Srigutomo, "Pemodelan Aliran Fluida 2-D Pada Kasus Aliran Permukaan Menggunakan Metode Beda Hingga," J. Mat. Sains, vol. 18, no. 3, pp. 81-92, 2013.

[14] S. Patimah, "Solusi numerik persamaan navier-stokes dua dimensi dengan metode beda hingga skema forward time central space." Universitas Islam Negeri Maulana Malik Ibrahim, 2016.

[15] F. A. Morrison, An introduction to fluid mechanics. Cambridge University Press, 2013.

[16] D. Halliday, R. Resnick, and J. Walker, "Fundamentals of Physics. V. 1, Part 2." John Wiley \& Sons, Inc, 2011.

[17] Y. Nakayama, Introduction to fluid mechanics. Butterworth-Heinemann, 2018.

[18] E. J. Purcell, D. E. Varberg, and I. N. Susila, Kalkulus dan geometri analitis (jilid 1). Erlangga, 1987.

[19] R. Larson and B. H. Edwards, Calculus: Early transcendental functions. Cengage Learning, 2010.

[20] M. Braun and M. Golubitsky, Differential equations and their applications, vol. 1. Springer, 1983.

[21] W. A. Strauss, Partial differential equations: An introduction. John Wiley \& Sons, 2007.

[22] H.-O. Kreiss and J. Lorenz, Initial-boundary value problems and the Navier-Stokes equations. SIAM, 2004.

[23] T. J. R. Hughes and J. E. Marsden, A short course in fluid mechanics, no. 6. Publish or Perish, 1976. 